\title{
Variation of Manganese Oxide Textures and Geochemistry with Rock Association at the Yakau Area, Ghana
}

\author{
Ernest Kojo Odum ${ }^{1}$, Felix Oppong ${ }^{2}$, Andrews Agyirey-Kwakye ${ }^{3}$, Francis Adjei Jarchie ${ }^{4}$
}

${ }^{1,3}$ Department of Geological Engineering, University of Mines and Technology (UMaT), P.O. Box 237, Tarkwa, Ghana

${ }^{2}$ School of Resource and Environmental Engineering, Wuhan University of Science and Technology, Wuhan 430081, PR China

${ }^{4}$ Department of Minerals Engineering, University of Mines and Technology, P.O. Box 237, Tarkwa, Ghana

\begin{abstract}
Twelve highly weathered residual oxide samples from outcrops at Yakau and Bofun near Dixcove show massive, vuggy, striations of foliation, and fibrous-banded textures. The partially oxidised primary rock identified as amphibolite garnet - gneiss, which contains garnet $30 \%$, amphiboles $35 \%$, quartz $15 \%$ and ore minerals $5 \%$ with garnet partially replaced by recrystallised quartz and manganese minerals, mainly pyrolusite. There are manganese oxide residuals that contain quartz 20\%, todorokite and pyrolusite $50 \%$, goethite $30 \%$, and garnet replaced by goethite. The vuggy textured residual oxide contains the highest mangane se oxide (61.0 wt \%), whereas the fibrous-banded type contains the least manganese oxide (1.8 wt \%). It is recommended that stages of oxidation of the oxides be studied further to know the extent of maturity of oxides, which may contain higher MnO grades, as well as the textures of the oxides to be used as an additional tool for mineral exploration. Observations made from the scatter plots indicate a correlation coefficient of elements within the ores and rocks. The correlation coefficient $(r)$ between some elements show a strong/positive correlation whereas others show a negative/weak correlation.
\end{abstract}

Keywords: Institute, Manganiferrous Black, Striated Foliated, Fibrous Banded, Vuggy Types, Pyroclastic Rocks.

\section{INTRODUCTION}

The world's manganese deposits are classified into three genetic types: sedimentary, hydrothermal and superficial. The sedimentary type encompasses both volcanogenic and non-volcanogenic sediments (ancient continental deposits and recent deepsea nodules) and their metamorphosed equivalents. Sedimentary deposits of manganese are the most abundant of all manganese deposits [1]. The sedimentary manganese ore type can be divided into two major classifications with each subdivided based on rock associations. These are non-volcanogenic types, associated with iron formation, and limestone-dolomite formation [2].

The superficial manganese type is formed by residual concentration from meteoric waters and by supergene oxidation-enrichment of pre-existing manganese formations [1]. Further processes such as chemical weathering, transportation of the weathered materials by groundwater as well as precipitation of minerals enhances the formation of manganese oxides [3]. The hydrothermal type includes hypogene vein deposits and those formed in thermal spring aprons [1]. Hypogene vein of manganese from Bisbee and Tombstone, Arizona, United State of America consists of alabandite, minor rhodochrosite associated with copper, silver and gold ores [4].

According to [3], oxide textures can be studied as megascopic or microscopic; and has identified that the Janggun mine in Korea shows variation of textures such as dendritic or arborescent, fibrous, granular, massive, comb, geode, globular, and colloform textures. The Nsuta manganese deposit shows variation in textures such as vuggy, botryoidal, and massive to bedded and vein-like characters [5]. [6] has also stated the relationship between manganese oxides and textures at the Parnok mine. He mentioned that the massive deposit is composed of 35 to 78 percent manganese oxide, earthy contain 8 percent, and massive with rubbly contain 10 to 50 percent of manganese oxide. The lower part of the volcanic rocks at the Dixcove area consist of pillowed basalts and tuffs with a good exposure at Butre, are inter-bedded with manganiferous rocks composed of chert, manganese oxide and carbonate minerals [7]. [8] has classified manganese oxide deposit at the Dixcove area based on structures and textures which are subdivided 
into detrital ores (eluvial talus), hard-spongy ores (iron-manganese, oxidised gondite) and massive crystalline (non-oxidised gondite).

However, there are no information on the relationship between the oxide textures and the geochemistry of the Yakau manganese oxide deposit as shown in work of [6]. This work is aimed at investigating the variation of manganese oxide textures with respect to the geochemical composition at Yakau area in the Dixcove manganese oxide deposit.

\section{INFORMATION ABOUT THE PROJECT AREA}

\subsection{Location and Accessibility}

The study area, Yakau is located in the Ahanta West district, which is about $35 \mathrm{~km}$ to the west of Sekondi-Takoradi and about 250 $\mathrm{km}$ southwest of Accra [9]. Yakau is a small farming community located at the northwest of Dixcove in the Western region of Ghana [10]. Yakau, Bofun and its surrounded towns are described as being covered with a lot of hills and is very well-watered, heavily forested with very fertile soils and very rich in gold which the natives dug out of the earth and from river beds [10]. Yakau is between Sankor and Bofun. Sankor is about $0.8 \mathrm{~km}$ from Yakau [8]. The sampling location can be seen from fig. 1.

\subsection{Topography and Drainage}

Yakau and its environs is located generally within mountainous ranges covered by massive rubber vegetation. Precipitation is about $1514 \mathrm{~mm}$ annually. Rainfall in the area is rampant especially from March to July and at the later part of the year with a variation in precipitation between the driest and the wettest months of about $343 \mathrm{~mm}$. The two villages, Yakau and Bofun lies within an area with several gentle hills that are about 20 to $70 \mathrm{~m}$ above sea level and are covered with plantations and forest reserves [10].

The Dixcove and its environs are in the Ahanta west of the Western Region of Ghana with drainage pattern primarily dendritic with several of the streams and rivers being seasonal flows. The major streams in the Dixcove area include the Busua and Mawu which flow into the Nfuma Lagoon while Butre, Apesuro, Whin, Suoni, Nyila, Yani and Nyame makes up the principal rivers in the Dixcove and its environs and some of these rivers are known to take up their source from the hills around Banso Egyambra and Cape Three Points $[11 ; 10]$.

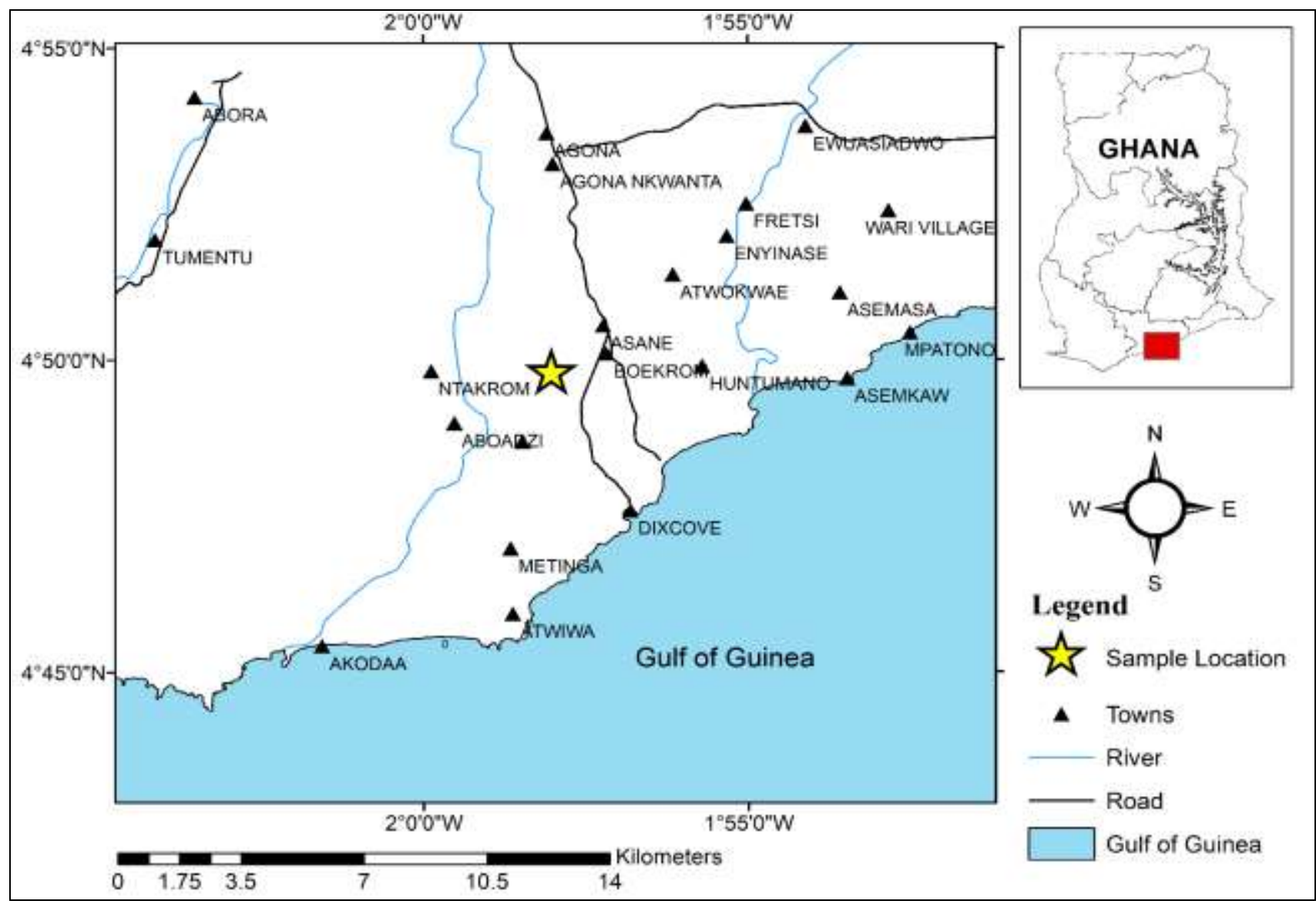

Fig. 1: Map of Southern Part of Ghana showing Sampling Locations (Yakau and Bofun) 
International Journal of Advances in Scientific Research and Engineering (ijasre), Vol 6 (3), March -2020

\subsection{Geology setting}

The Dixcove falls within the Birimian Palaeoproterozoic rocks of the West African Craton, which was described to consist of meta-sedimentary rocks and meta-volcanic unit [12]. It is contemporaneous lithostratigraphic supergroup with lateral facies of rock units composing of volcanic, pyroclastic and sedimentary rocks [13-14]. Palaeoproterozoic Birimian volcanic rocks at Yakau is also within the Dixcove complex granitoid which is intruded along deep-seated faults in three distinct phases which follow one another from basic to acidic: gabbro-diorite-granodiorite [15-18]. The Birimian rocks at Dixcove are completely weathered and eroded in Asani-Himakrom-Tontu. The phyllites between Yakau and Bofun, strikes slightly northeast. The greater portion of the Yakau manganese deposits area which covers Asani, east and west of Yakau, Kowuako, Bofun-Elubankata and Kwesikrom consist of enriched replaced phyllites, sediments and tuffs [8].

Manganese oxides are usually formed at the interface between the lithosphere and hydrosphere as well as the atmosphere and or the biosphere [19]. According to [7] the lower part of the volcanic rocks that are exposed at east of Dixcove consist of pillow basalts and tuffs interbedded with manganiferous rocks composed of chert, manganese oxide and carbonate minerals.

The geochemical behaviour of manganese is similar to magnesium $(\mathrm{Mg})$, iron (Fe) and Nickel (Ni). Manganese bearing rocks are oxidised when they interact with surface and ground water [19]. Oxidation reaction is rampant at the surface of the earth which results in formation of manganese minerals [20]. Manganese oxides are the most economically exploitable manganese deposits, formed by weathering of manganese rich carbonates or silicates, by in-situ oxidation or by dissolution followed by migration and precipitation [21]. They are classified as richly oxidised containing 15 to 57 percent $\mathrm{Mn}$ and 35 to $78 \mathrm{MnO}_{2}$, poorly oxidised with 10 to 15 percent $\mathrm{Mn}$ and 1.5 to 11 percent $\mathrm{MnO}_{2}$, semi oxidised with 20 to 42 percent $\mathrm{Mn}$ and 10 to 50 percent $\mathrm{MnO}_{2}$, Oxidised ferromanganese with 10 to 30 percent Manganese [6]. The geological map showing sampling location can be seen from fig. 2.

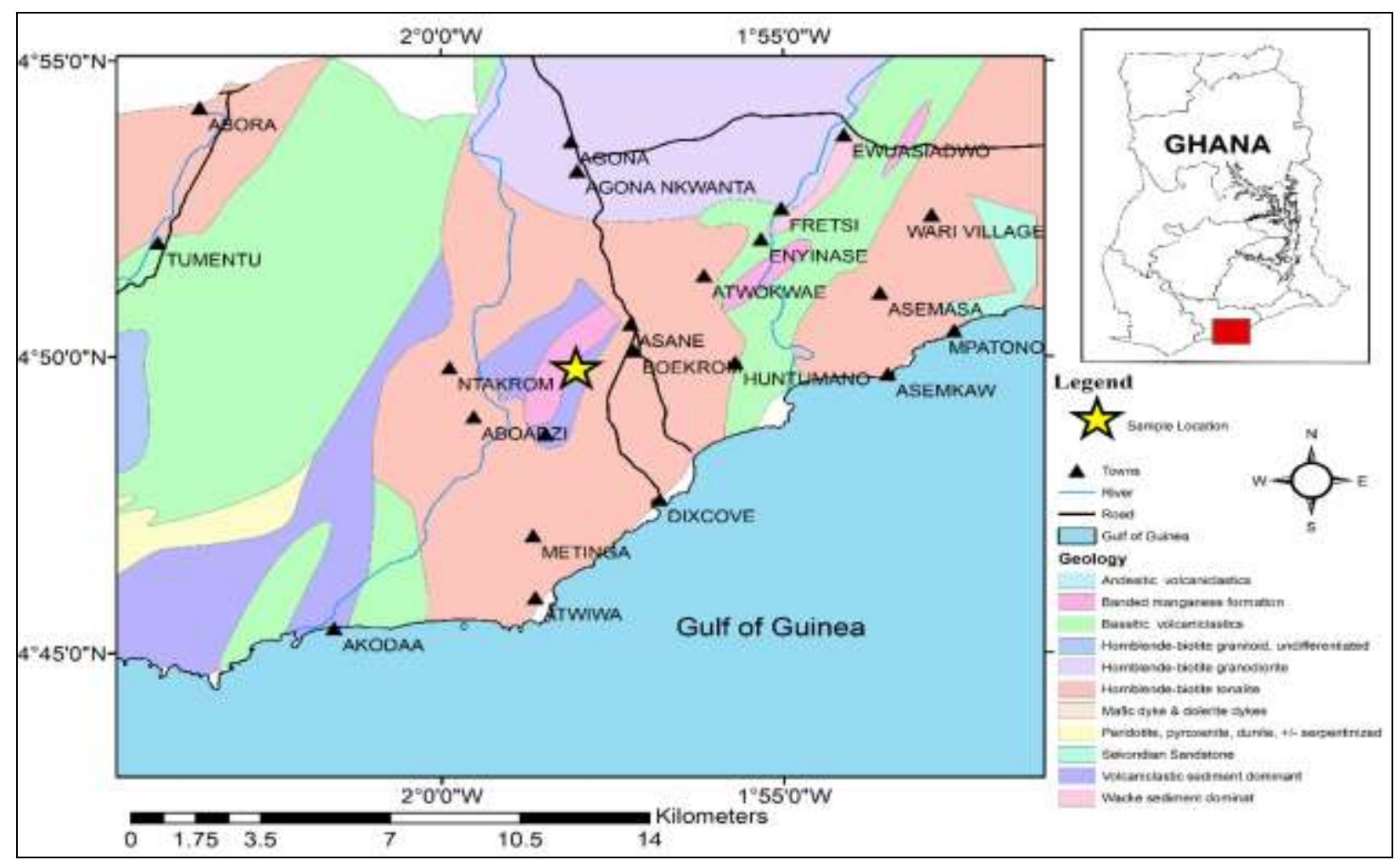

Fig. 2: Geological map of the Southern Part of Ghana showing the Sampling Locations

\subsection{Climate and Vegetation}

According to [22] the average maximum rainfall recorded in the Yakau area and its environs is about $1700 \mathrm{~mm}$ meanwhile the lowest rainfall is usually recorded in the month of February but the volume and pattern of precipitation is inconsistent. Rainy season in the area usually starts around April and ends in September, where the greatest volume of precipitation occurs between the months of April and July [10]. 


\section{International Journal of Advances in Scientific Research and Engineering (ijasre), Vol 6 (3), March -2020}

The area falls largely within the high rain forest vegetation zone, capturing several hectares of rubber plantation whose influence apparently reduce the issues of global warming, since the vegetation aid as a sink for $\mathrm{CO} 2$ emissions [17]. According to [10] the various villages that engage in the activities of farming are mostly seen to have an increase in farming activities during the rainy season. The average temperatures that are recorded in the Yakau area and its environs are usually higher throughout the year; about $34^{\circ}$ centigrade in hottest month of March. The lowest temperature is usually recorded in the month of August which is the coldest month with temperatures dropping to about $20^{\circ}$ centigrade [23]. Dixcove is in the Western Region as a result its surrounding villages are in the high rain forest zone which extends from south-western coast of Ghana to a latitude of about $7^{\circ} 45^{\prime} 00^{\prime \prime}[22]$. The vegetation zone is characterised by floristic variation as one move northwards due to decreasing amounts of rainfall. Currently the people in the Yakau area are more engaged in cocoa, palm and rubber plantations [10].

\subsection{Mining History of Dixcove area}

According to [8], Mr. J. E. Cudjoe was the first to have ever published a detailed information on geology, structure, types of ore and the promising reserves at the Yakau Himakrom in the 1956. Most of the mining activities in the Yakau-Himakrom area started in the year 1940 to 1954 by different manganese companies. During this period, the greater part of exploitation was carried out by the Yakau manganese company, about 22,210 tonnes of manganese ore were exploited and exported from the faces developed at Asani, Eastern and Western Yakau, Kowuako, and Bofun by the open-cast.
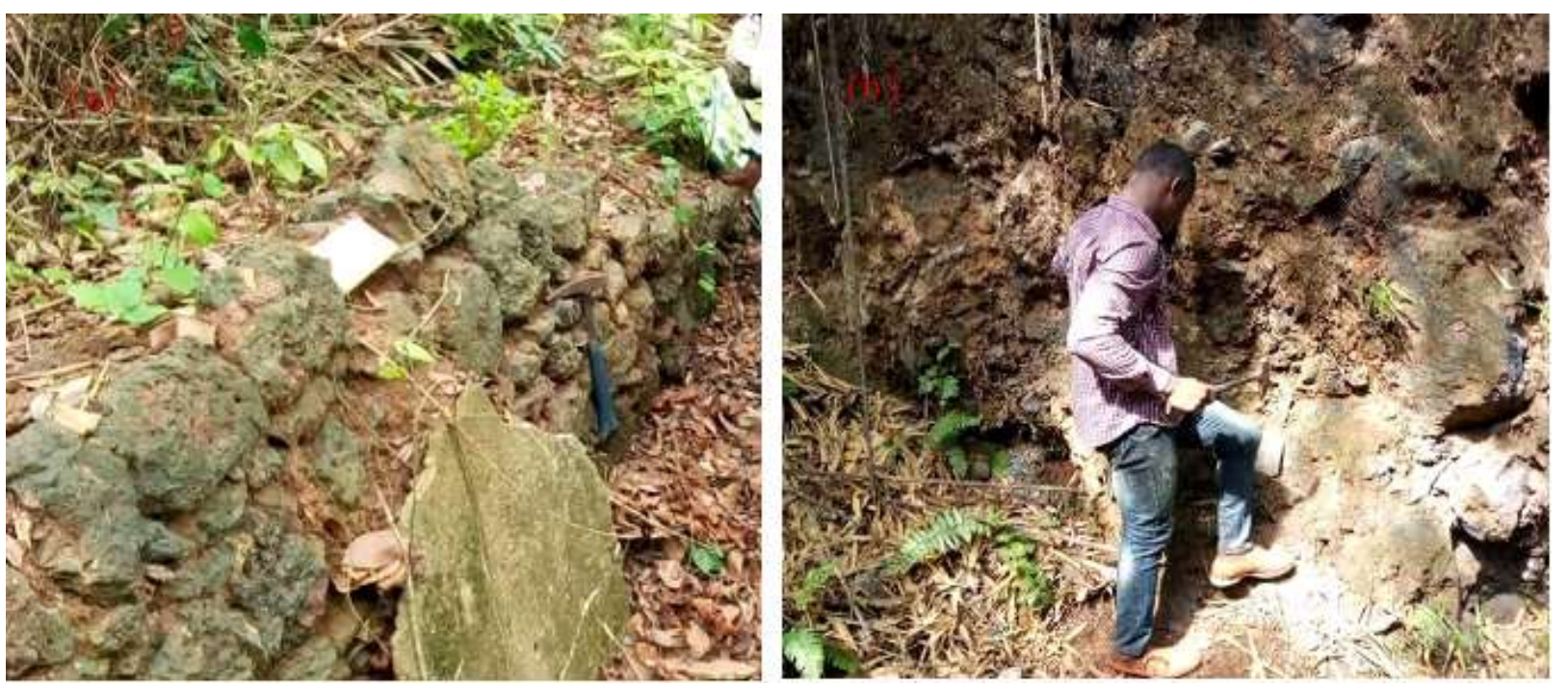

Fig. 3: Photograph of manganese oxide at (a) abandoned mine heap in Yakau (b) Yakau hill outcrop

\section{METHODS USED}

Three major methods were used to acquire data and results for the project. These methods include Field work, laboratory tests and data analysis.

\subsection{Field Work}

Twelve samples were collected from highly weathered bulk materials in different localities at Yakau and Bofun within the Dixcove area. The samples were described in hand specimen with the aid of a hand held lens to determine the textural characteristics. The samples were labelled and bagged. At every point of sampling, the coordinates were recorded with a handheld GPS device as well as the strike and dip of the outcrops determined using a geological compass. The sample ID and the location are shown in the appendix A.

\subsection{Laboratory Test}

Each of the twelve samples were cut into three, a third was taken to the Environmental and Safety laboratory at University of Mine and Technology for X-Ray Fluorescence analysis, eight samples were taken to GMC for similar analysis. Thin sections were prepared out of sample one (The partially oxidised primary rock) and two for microscopic studies with the help of the transmitting light petrographic Leica microscope, in both plane and crossed polarised light at the Petrology Laboratory in the University of Mines and Technology. 


\section{International Journal of Advances in Scientific Research and Engineering (ijasre), Vol 6 (3), March -2020}

The samples were grinded into fine grain (38micron) using the balls grinder at the Minerals Laboratory at the University of Mines and Technology, sieved with a 38-micron sieve size and bagged. At the Environmental and Safety Laboratory of University of Mines and Technology, Tarkwa, the X-Ray Fluorescence Oxford XMET7000 Express device was used to analysed the elemental composition of each sample. The results were downloaded and displayed on the attached computer. Microsoft Excel was used to process results for these measurements. OriginPro 9.0 was also used for the generation of correlation coefficient diagrams and scatter plots

\section{RESULTS AND DISCUSSION}

\subsection{Petrographic Observation and Analysis made under the Microscope}

\subsubsection{Partially Oxidised Rock (Striated foliation type)}

The microscopic study shows that the partially oxidised primary rock has granular garnets breaking down to form manganese and amphiboles. From fig. 4 the recrystallised quartz and ore minerals partially replaced the garnet with amphiboles at the margins of the garnet. The modal percentage of the partially oxidised rock is shown in table 1:

Table 1. Modal percentage of partially Oxidised rock (amphibole-garnet-gneiss) at Yakau.

\begin{tabular}{|c|c|}
\hline Minerals & $\begin{array}{c}\text { Modal } \\
\text { percentage }(\%)\end{array}$ \\
\hline Amphibole & 30 \\
\hline Quartz & 15 \\
\hline Garnet & 35 \\
\hline Muscovite & 5 \\
\hline Chlorite & 5 \\
\hline Plagioclase & 5 \\
\hline Ore minerals & 5 \\
\hline Total & 100 \\
\hline
\end{tabular}
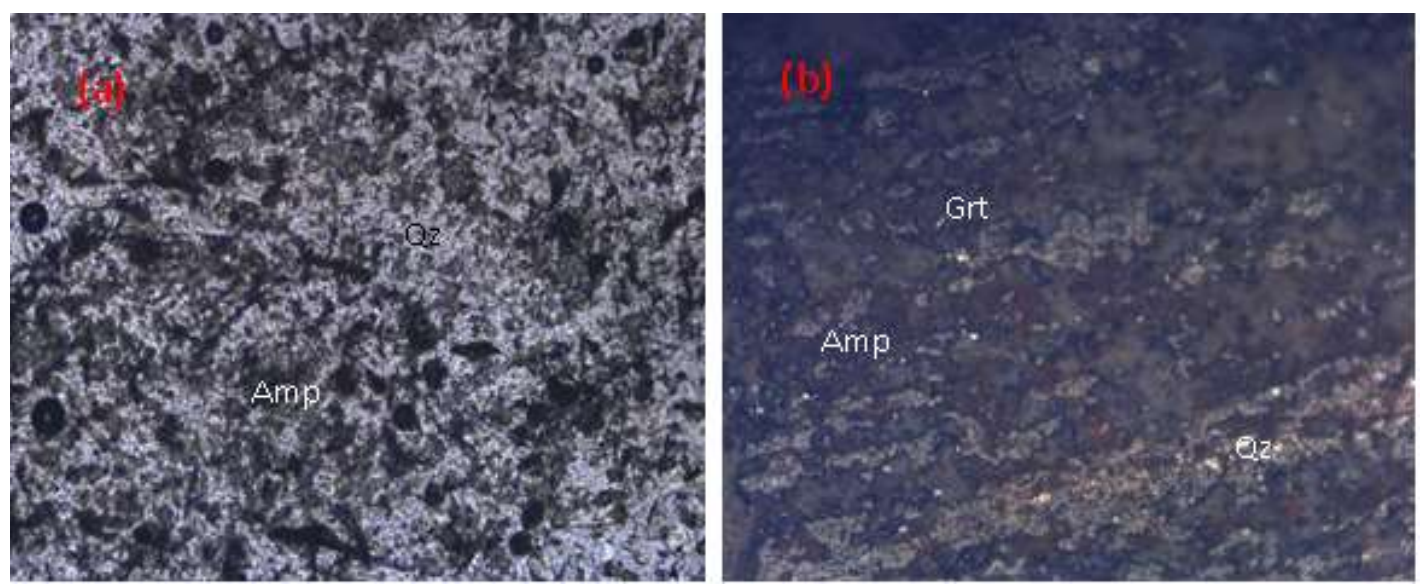

Fig. 4: Photomicrograph of amphibole-garnet-gneiss showing (a) alternation of amphibole and quartz rich foliation (b) garnet partially replaced by quartz and ore minerals with amphiboles at the margins.

\subsubsection{Manganese Oxide}

There is recrystallisation of quartz along fractures with the ore mineral goethite occurring around fractures and grain boundaries of quartz. The mineral todorokite cuts across pyrolusite with garnet replaced by goethite, quartz and ore minerals, this can be observed at fig. 5. The modal composition of minerals in the manganese oxide is shown in table 2 : 
International Journal of Advances in Scientific Research and Engineering (ijasre), Vol 6 (3), March -2020

Table 2. Modal percentage of residual manganese oxide at Yakau.

\begin{tabular}{|c|c|}
\hline Minerals & $\begin{array}{c}\text { Modal } \\
\text { percentage (\%) }\end{array}$ \\
\hline Quartz & 20 \\
\hline Goethite & 30 \\
\hline Ore minerals & 50 \\
\hline Total & 100 \\
\hline
\end{tabular}
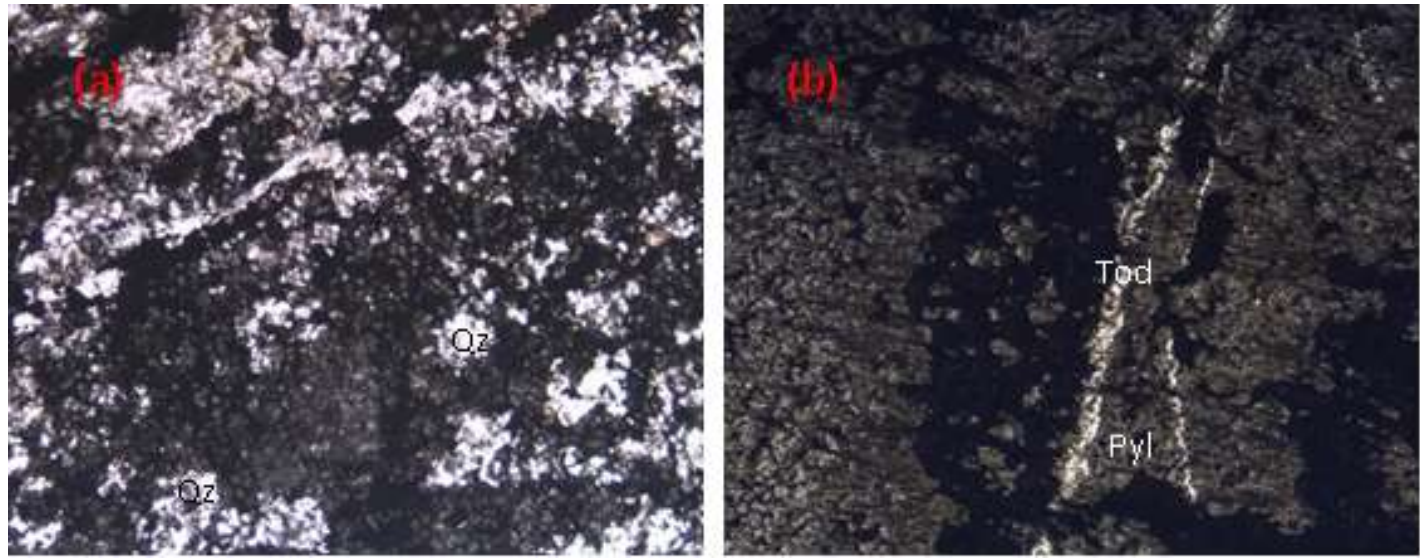

Fig. 5: Photomicrograph of manganese oxide showing (a) goethite occurring along grains of recrystallised quartz $(\mathrm{b})$ todorokite cutting across pyrolusite

\subsection{Textural Identification and Analysis on Rock Samples}

\subsubsection{Striated Foliated Type}

The striated of foliation type is a dark-grey with black to brown and creamy-white veinlets (recrystallised quartz) running through it. The grains are granular and fine grains with fractures filled with carbonate (Fig. 6).
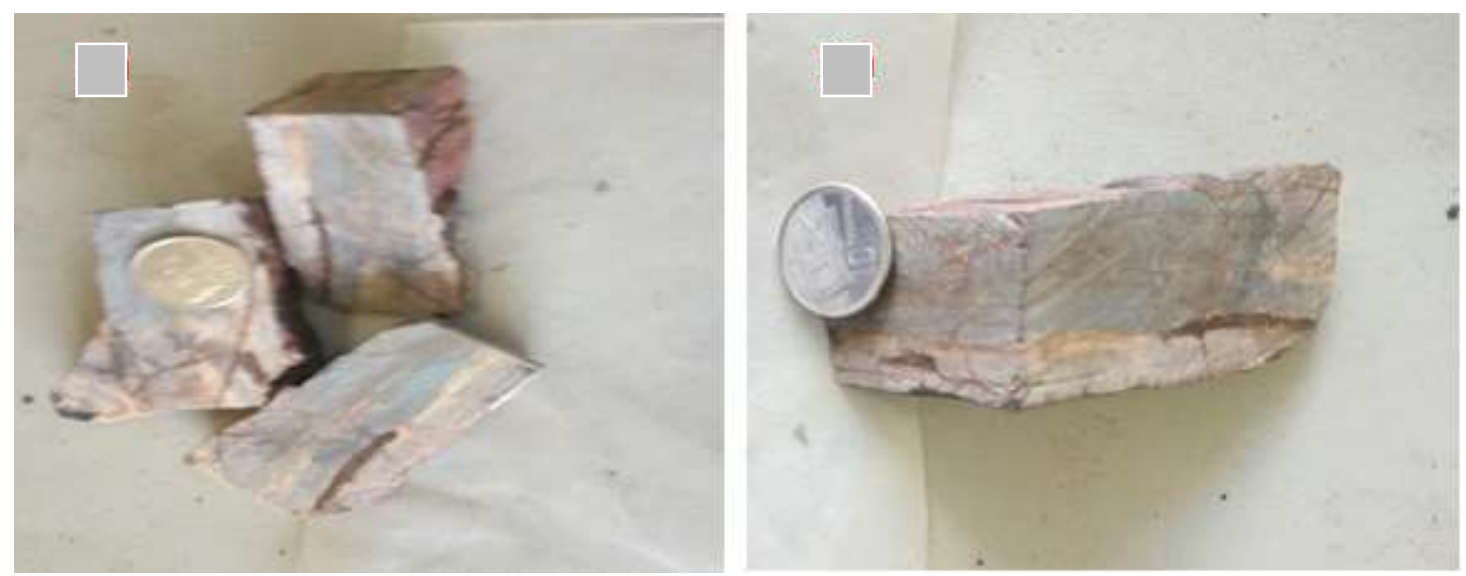

Fig. 6: Striated foliation with chocolate-brown veinlets.

\subsubsection{Massive Types}

A. Massive black with brown coloration (a) and Massive black with cream veinlets and lenses (b)

The massive black with brown oxide is hard. The grains are granular and fine with recrystallised quartz veins and lenses running through it. The black colour looks as though it was burnt in fire (a). The massive black with cream veinlets and lenses type of rock contains recrystallised quartz veinlets, lenses and the grains are granular. There are fractures through the rock and at the edge (b) (Fig. 7). 
International Journal of Advances in Scientific Research and Engineering (ijasre), Vol 6 (3), March -2020

B. Massive with cream bands and orange lenses

This type of oxide rock has cream to orange bands and lenses. Some portion of the sample is made of a brown-black (Mn-rich) mineral and other portions are of pale cream to brown (Silica- rich). The black coloration overrides the cream bands and orange lenses (Fig. 8).

C. Massive black with brown patches

The massive black with brown patches oxide type has granular fine grain of minerals, with about one percent cavities at edge (a). There are also brown-black earthy patches at the edges of the oxide rock sample (b) (Fig. 9).

D. Massive black with orange-brown patches

This type of oxide rock has black with orange-brown patches. The sample contains about 5 percent cavities running through the edges. There are orange-brown patches at the external part of the rock sample (Fig. 10).
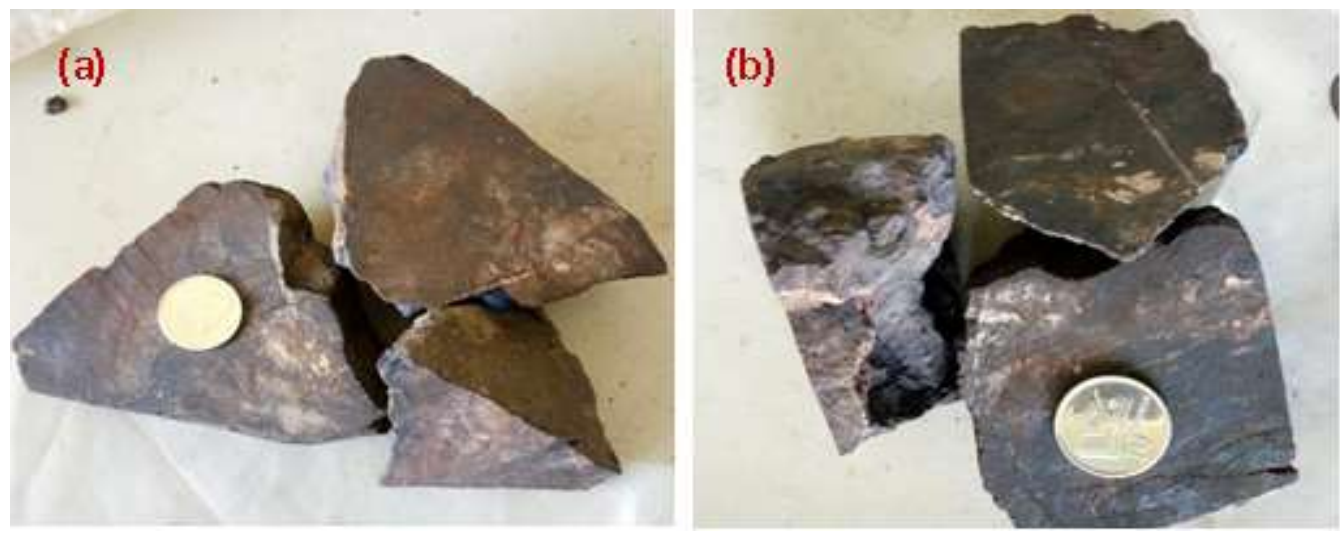

Fig. 7: Massive black type with (a) brown coloration and granular fine grains (b) fractures cutting across the quartz vein.
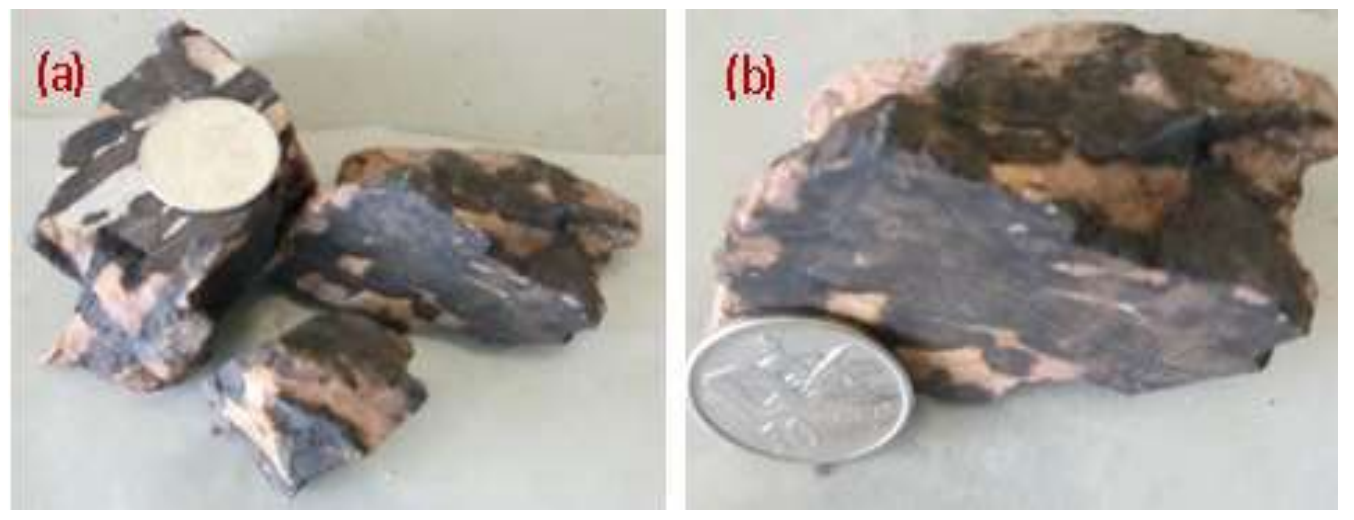

Fig. 8: Massive type with (a) orange-brown to cream lenses and black bands (b) white to orange-brown lenses and patches 
International Journal of Advances in Scientific Research and Engineering (ijasre), Vol 6 (3), March -2020
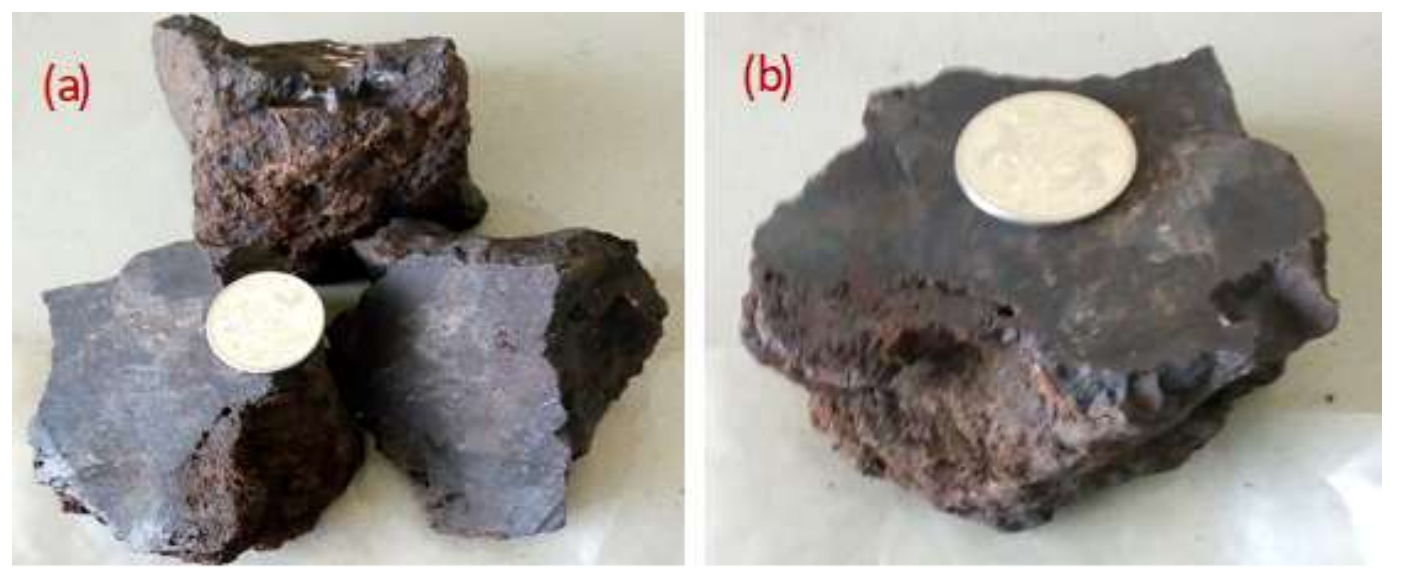

Fig. 9: (a) and (b) Massive black type with chocolate-brown patches and granular grains.
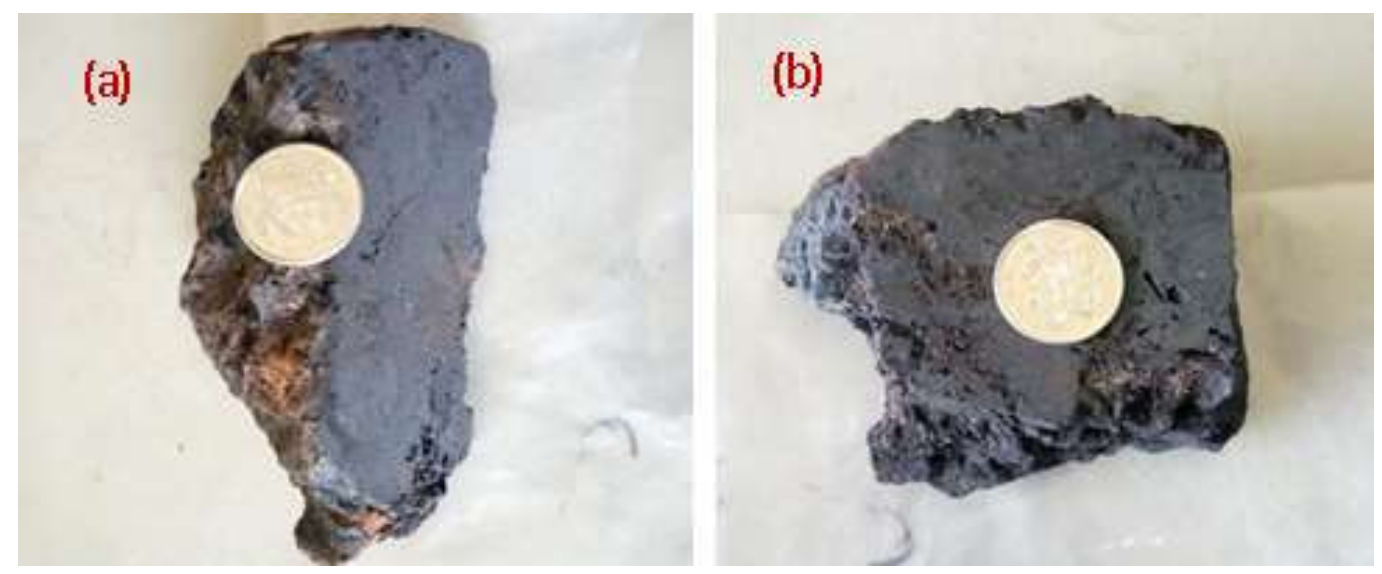

Fig. 10: Massive black type with (a) orange-bronwn to chocolate-brown patches and fractures (b)chocolate brown stains and few cavities

\subsubsection{Fibrous-banded Type}

This type of oxide rock is an orange-brown hard with fine-grained minerals. The sample also shows reddish-brown and orange wavy banding with grey spots. There is a fracture joint in the rock (Fig. 11).
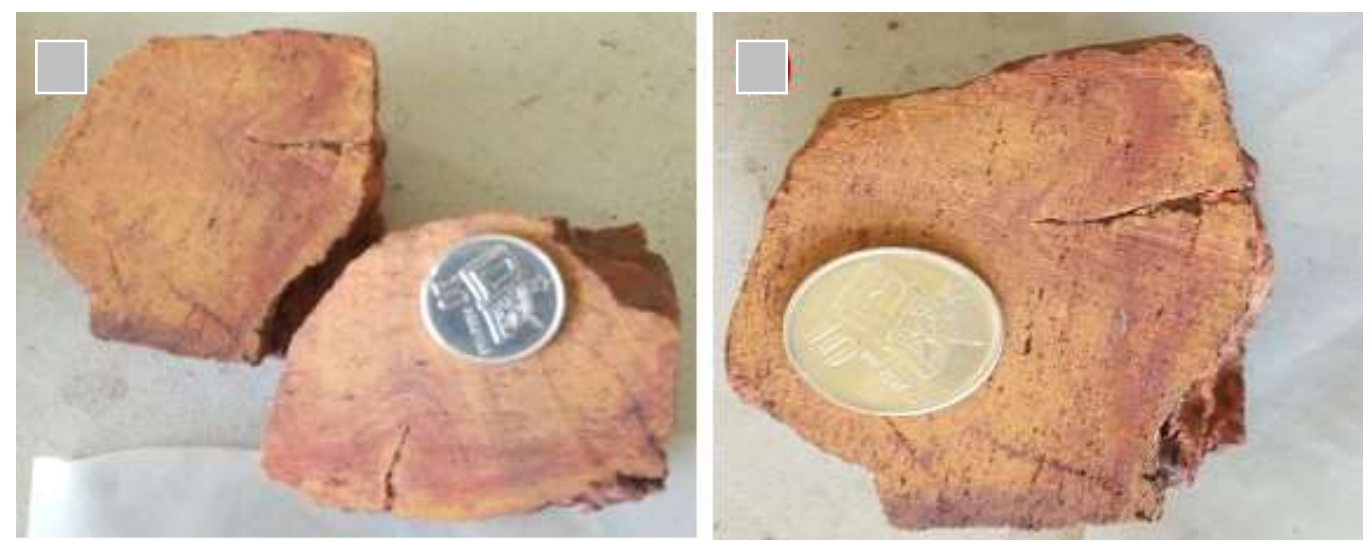

Fig. 11: Fibrous-banded type with chocolate-brown to reddish-brown bands, a fracture, and a joint

\subsubsection{Vuggy types}

A. Vuggy: $50-60 \%$ cavities

The vuggy: $50-60 \%$ cavities type has diameters of cavities ranging from $1 \mathrm{~mm}$ to $5 \mathrm{~mm}$ with some cavities being less than $1 \mathrm{~mm}$ in diameter. The cavities occupy 50 to $60 \%$ of the cut surface and external surface area of the sample, with depth ranging from 1 


\section{International Journal of Advances in Scientific Research and Engineering (ijasre), Vol 6 (3), March -2020}

$\mathrm{mm}$ to $5 \mathrm{~mm}$. Some cavities contain chocolate-brown earthy materials with black stains. The bulk sample is brown in colour with fine to medium grains (Fig. 12).

B. Vuggy: $40-50 \%$ cavities

This type of oxide is greyish-black with cavities of irregular shapes with diameters ranging from $1 \mathrm{~mm}$ to about $12 \mathrm{~mm}$. The cavities cover about 40 to $50 \%$ of the rock surface area with depths ranging from $1 \mathrm{~mm}$ to $3 \mathrm{~mm}$. There are brown earthy materials occupying some of the cavities (Fig. 13).

C. Vuggy: $50-60 \%$ cavities with striations

This oxide type is a brown rock with black and yellow striations. The cavities have diameters ranging from $1 \mathrm{~mm}$ to $3 \mathrm{~mm}$. There are spots of yellow coloration and chocolate-brown earthy materials occupying some of the cavities at the external part of the sample with some striations at the external part of the sample (Fig. 14).

D. Vuggy: $50-60 \%$ cavities with botryoidal

This type of oxide is a hard-black rock with some portions showing botryoidal texture of globular diameter ranging from 2 mm to $4 \mathrm{~mm}$. The cavities vary in diameter from $1 \mathrm{~mm}$ to $10 \mathrm{~mm}$ with depth ranging from $2 \mathrm{~mm}$ to $12 \mathrm{~mm}$ occupying $50-60 \%$ of the cut surface and external surface of the sample. Some of the cavities are field with brown earthy materials. There is globular growth within some of the cavities with diameters ranging from $3 \mathrm{~mm}$ to $5 \mathrm{~mm}$. The grain sizes are fine to medium (Fig. 15).

E. Vuggy: $60-70 \%$ cavities with botryoidal

The vuggy: $60-70 \%$ cavities with botryoidal oxide type is a black rock with cavities of different sizes and shapes of diameters ranging from $1 \mathrm{~mm}$ to $8 \mathrm{~mm}$. They occupy 60 to $70 \%$ of the surface area with depths ranging from $1 \mathrm{~mm}$ to $10 \mathrm{~mm}$. There are three predominant coloration of the sample, which are the reddish-brown patches, chocolate brown stains and earthy materials occupying the cavities with black stains, the globular are of diameters ranging from $1 \mathrm{~mm}$ to $2 \mathrm{~mm}$ (Fig. 16).
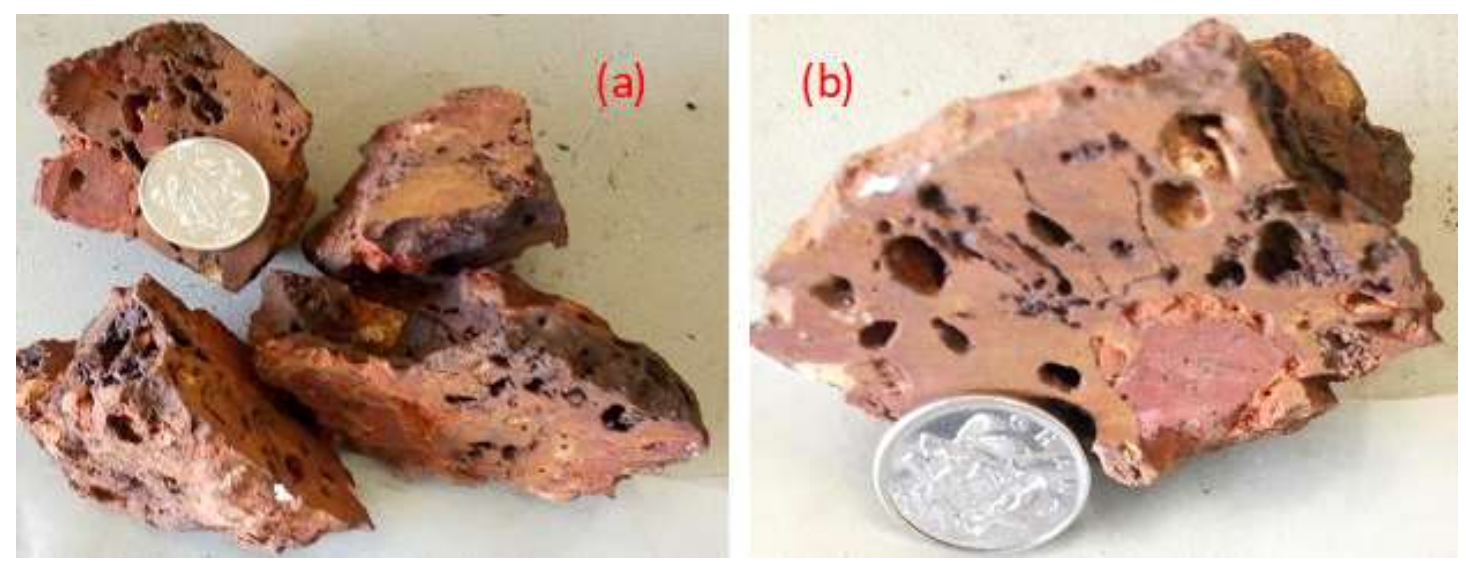

Fig. 12: Vuggy brown: 50 - $60 \%$ type with (a) cavities occupied by chocolate-brown and reddish-brown materials and black spots (b) embedded reddish-brown earthy material surrounded by orange material and black spots. 
International Journal of Advances in Scientific Research and Engineering (ijasre), Vol 6 (3), March -2020
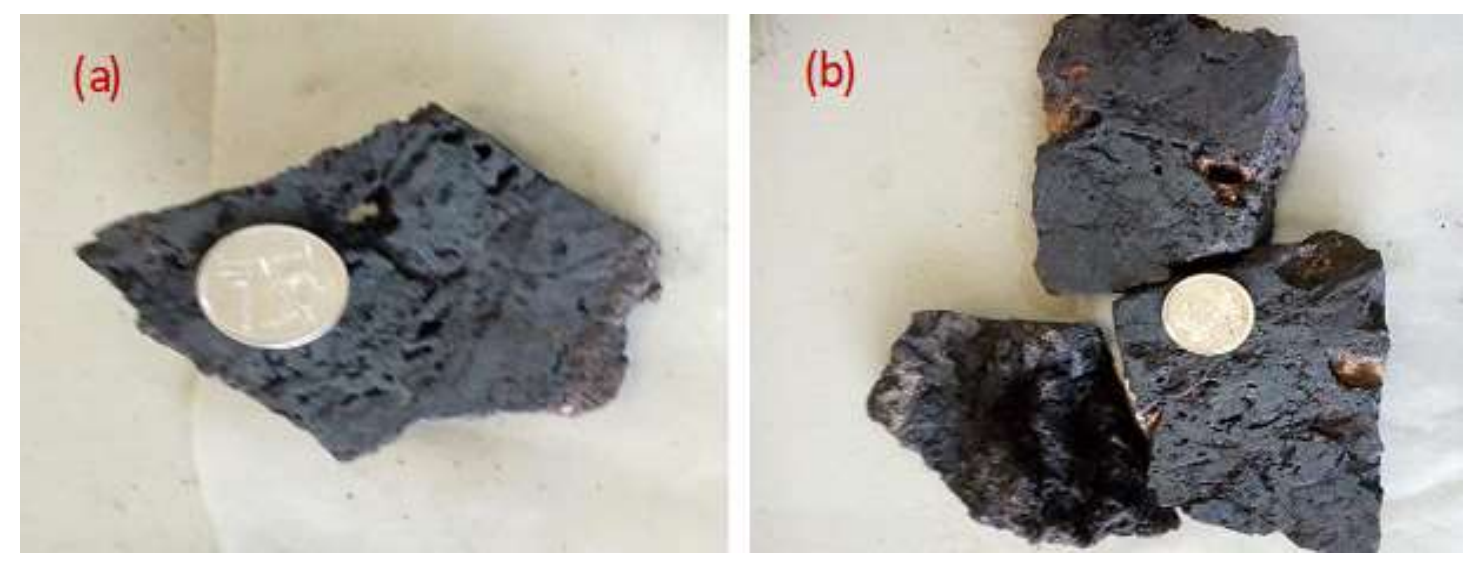

Fig. 13: Vuggy: 40 - $50 \%$ type with (a) irregular elongated cavities (b) cavities occupied by orangebrown medium grains of earthy material.
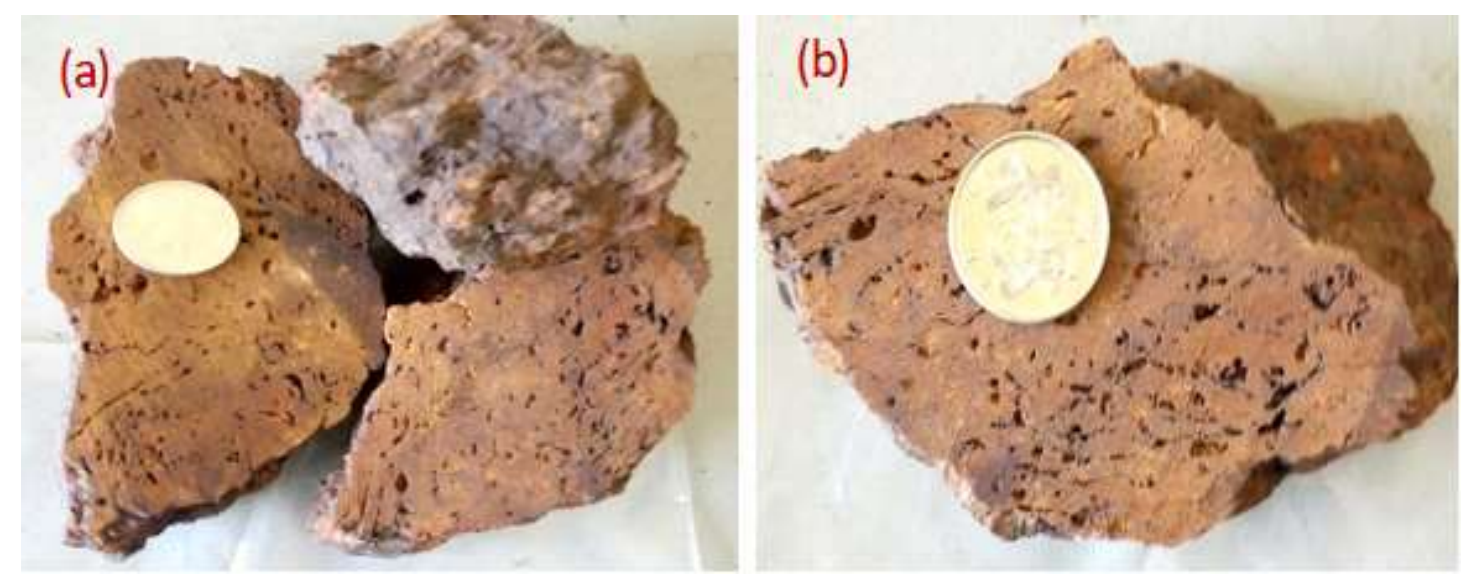

Fig. 14: Vuggy brown: 50 - $60 \%$ cavities with striations showing (a) black spots and yellow striations b) cavities occupied by chocolate-brown and yellow materials with yellow and black spots.
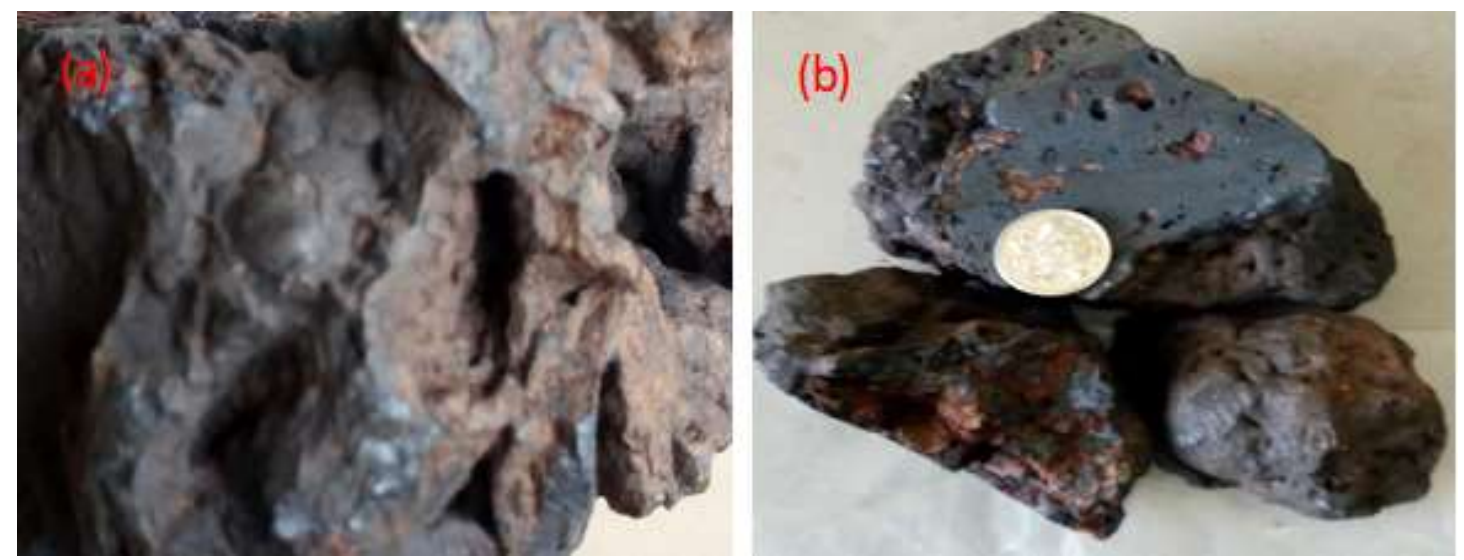

Fig. 15: Vuggy: 50 - $60 \%$ cavities with botryoidal showing (a) large cavities with globular growths (b) cavities occupied by chocolate-brown earthy materials with brown stains and patches. 
International Journal of Advances in Scientific Research and Engineering (ijasre), Vol 6 (3), March -2020
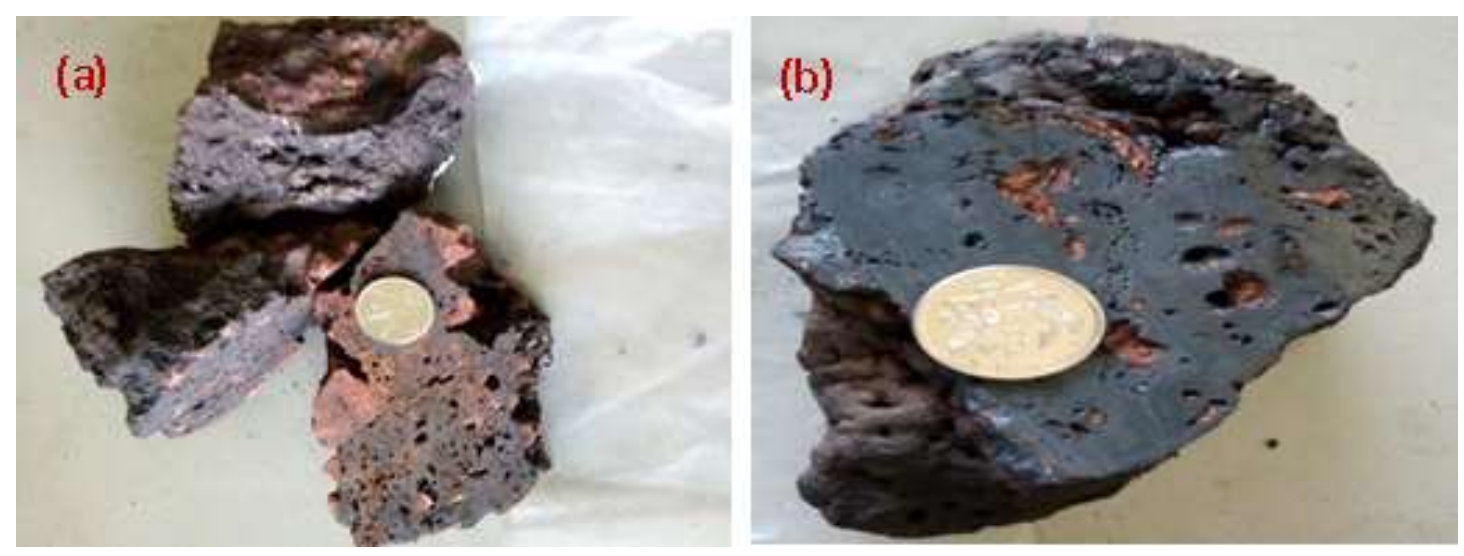

Fig. 16: Vuggy: 60 - $70 \%$ cavities with botryoidal showing (a) reddish-brown patches (b) cavities occupied with brown earthy material with globular growths.

\subsection{Geochemical Analysis Data}

The results obtained from the geochemical analysis of the major oxides Yakau manganese deposit is shown in table 3. Plots of $\mathrm{MnO} / \mathrm{FeO}_{\mathrm{t}}$ from geochemical analysis data against samples ID shows variation of $\mathrm{MnO}$ and $\mathrm{FeO}_{\mathrm{t}}$ with texture in Figs 17 and 18 respectively:

Table 3. Geochemical Data from X-ray Fluorescence Analysis

\begin{tabular}{|c|c|c|c|c|c|c|c|c|c|c|c|c|}
\hline SAMPLE & \multirow{2}{*}{ D1 } & \multirow{2}{*}{ D2 } & \multirow{2}{*}{ D3 } & \multirow{2}{*}{ D4 } & \multirow{2}{*}{ D5 } & \multirow{2}{*}{ D6 } & \multirow{2}{*}{ D7 } & \multirow{2}{*}{ D8 } & \multirow{2}{*}{ D9 } & \multirow{2}{*}{ D10 } & \multirow{2}{*}{ D11 } & \multirow{2}{*}{ D12 } \\
\hline ID/WT\% & & & & & & & & & & & & \\
\hline MnO & 6.08 & 33.6 & 19.9 & 19.9 & 1.84 & 0.96 & 1.93 & 45.4 & 23.2 & 60.9 & 36.6 & 58.9 \\
\hline $\mathrm{FeO}_{\mathrm{t}}$ & 2.88 & 6.32 & 8.1 & 8.72 & 62 & 71.3 & 54.1 & 3.32 & 33.1 & 4.08 & 7.69 & 3.26 \\
\hline $\mathrm{Al}_{2} \mathrm{O}_{3}$ & 29.72 & 19.7 & 23.4 & 22.7 & 11.7 & 9.26 & 14.7 & 16.5 & 14.0 & 11.6 & 18.1 & 12.5 \\
\hline $\mathrm{SiO}_{2}$ & 59.44 & 39.4 & 46.7 & 45.3 & 23.3 & 18.5 & 29.4 & 33 & 28.1 & 23.3 & 36.3 & 25.1 \\
\hline $\mathrm{TiO}_{2}$ & 0.1 & 0.17 & 0.28 & 0.47 & 1.13 & 0.09 & 0.52 & 0.13 & 0.41 & 0.14 & 0.27 & 0.18 \\
\hline $\mathbf{K}_{2} \mathbf{O}$ & 0.00 & 0.00 & 0.00 & 0.00 & 0.00 & 0.00 & 0.00 & 1.18 & 1.06 & 0.00 & 0.00 & 0.00 \\
\hline $\mathrm{CaO}$ & 1.69 & 0.79 & 1.58 & 2.85 & 0.00 & 0.00 & 0.41 & 0.29 & 0.00 & 0.00 & 1.07 & 0.00 \\
\hline Total & 99.91 & 100 & 100 & 100 & 100 & 100 & 99.4 & 100 & 100 & 100 & 100 & 100 \\
\hline
\end{tabular}


International Journal of Advances in Scientific Research and Engineering (ijasre), Vol 6 (3), March -2020

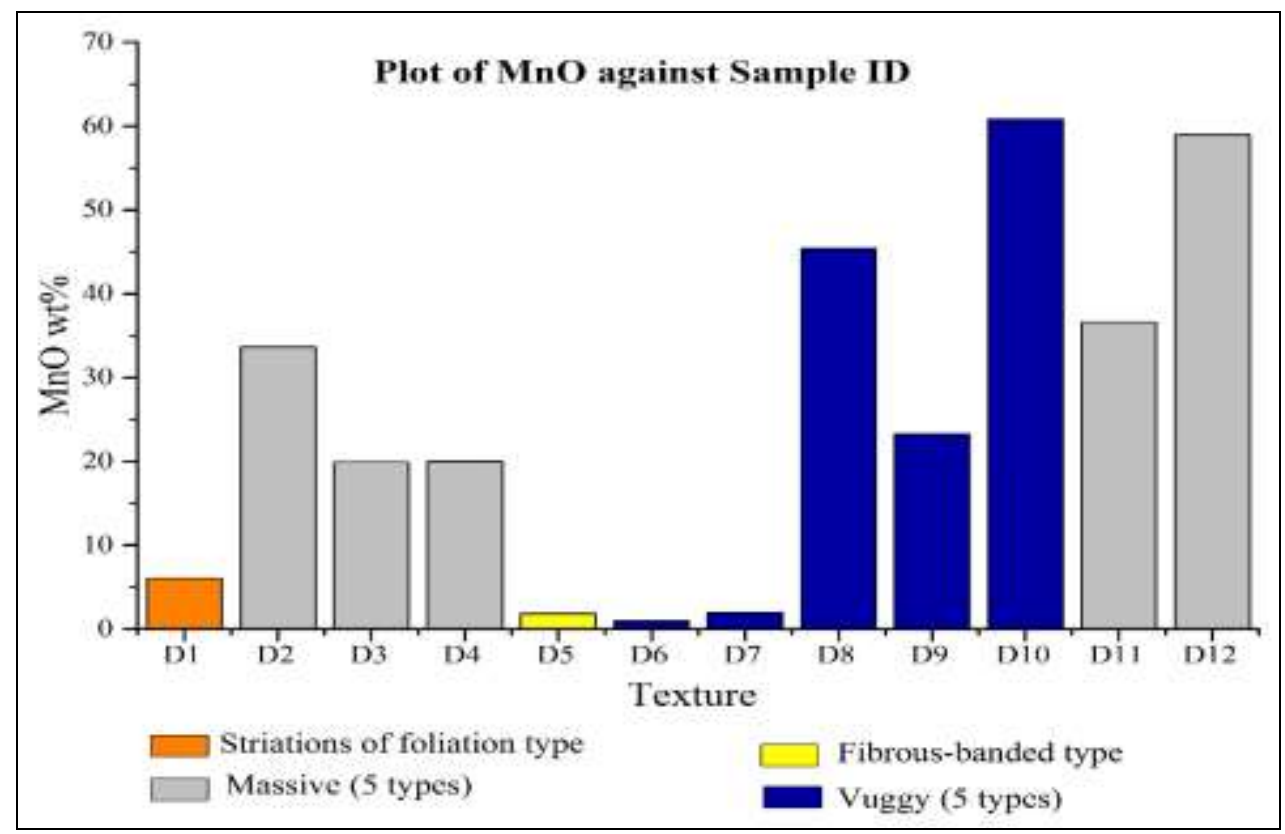

Fig. 17: Plot of $\mathrm{MnO}$ against sample ID showing variation of $\mathrm{MnO}$ with texture

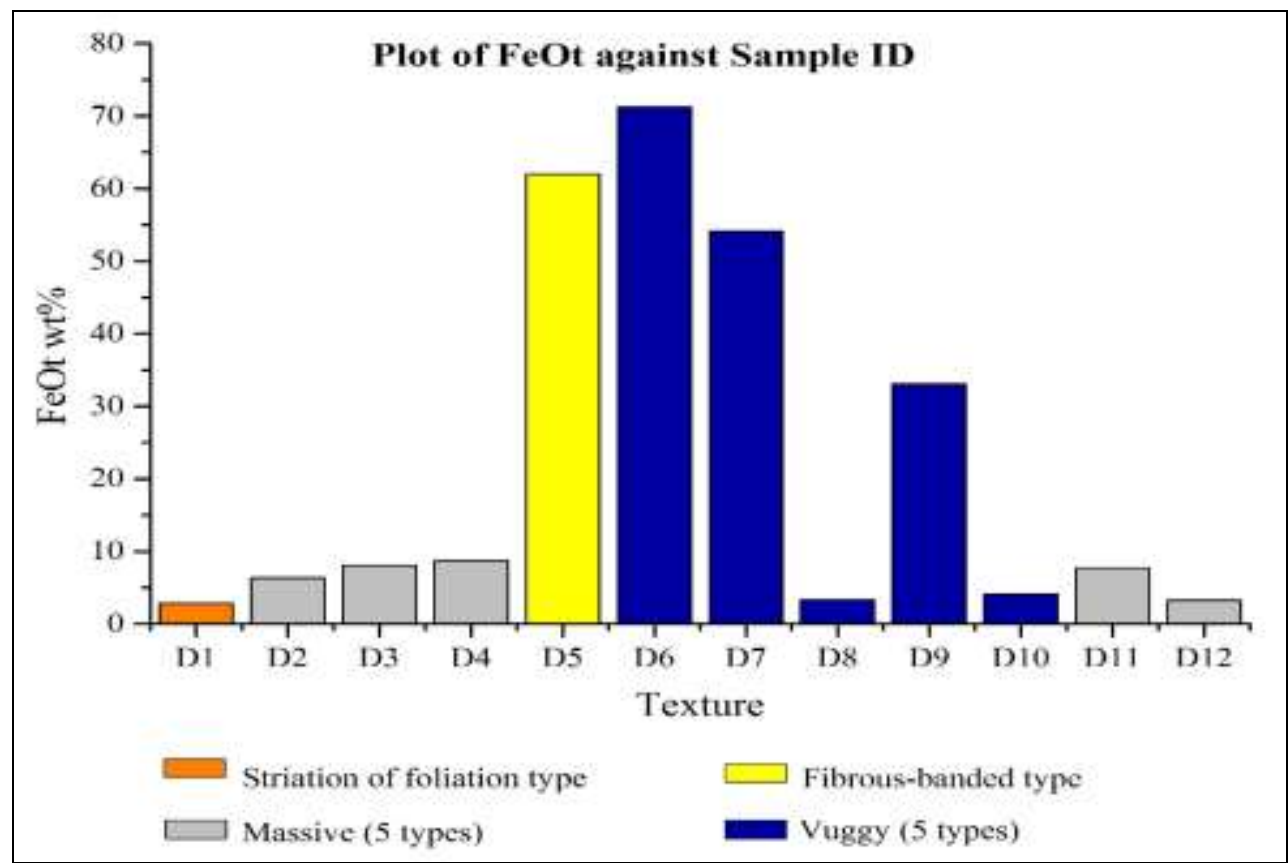

Fig.18: Plot of FeOt against sample ID showing variation of FeOt with texture

\subsection{1 $\mathrm{MnO}$ and Textures Relationships}

Manganese oxide at Yakau area is broadly classified into four types with their respective range of $\mathrm{MnO}$ shown in table 4, the four types are further classified into twelve in table 5 and the relationship between the $\mathrm{MnO}$ and textures shown in table 6 .

Table 4. Range of MnO Content in the Various Textures at Yakau area

\begin{tabular}{|c|c|c|}
\hline TEXTURES & SAMPLES & MnO wt \% \\
\hline Vuggy type & D6, D7, D8, D9, D10 & $1.93-61.0$ \\
\hline Striated foliation type & D1 & 6 \\
\hline Massive type & D2, D3, D4, D11, D12 & $19.91-58.9$ \\
\hline Fibrous-banded type & D5 & 1.8 \\
\hline
\end{tabular}


International Journal of Advances in Scientific Research and Engineering (ijasre), Vol 6 (3), March -2020

Table 5. Classification of Four Major Textures of the Oxides at Yakau area

\begin{tabular}{|c|c|c|}
\hline \multirow{4}{*}{ TEXTURE } & CLASSIFICATION & SAMPLE ID \\
\hline \multirow{4}{*}{ Massive } & Massive black with white veinlets and cream lenses & D2 \\
\cline { 2 - 3 } & Massive black with grey patches & D3 \\
\cline { 2 - 3 } & Massive black brown patches and white lenses & D11 \\
\cline { 2 - 3 } & Massive black with brown patches & D12 \\
\cline { 2 - 3 } & Massive with white bands and orange lenses & D4 \\
\hline \multirow{3}{*}{ Vuggy } & Vuggy: 50-60\% cavities with botryoidal. & D8 \\
\cline { 2 - 3 } & Vuggy: 60-70\% cavities with botryoidal. & D9 \\
\cline { 2 - 3 } & Vuggy with 40-50\% cavities & D10 \\
\cline { 2 - 3 } & Vuggy with 50-60\% cavities & D6 \\
\hline Fibrous-banded & Vuggy: $50-60 \%$ cavities with striations. & D5 \\
\hline Striated foliation & Fibrous with chocolate brown bands & D1 \\
\hline
\end{tabular}

Table 6. Relationship between Textures and Manganese Oxide Content at Yakau

\begin{tabular}{|c|c|c|c|}
\hline $\begin{array}{c}\text { SAMPLE } \\
\text { ID }\end{array}$ & TEXTURE & $\begin{array}{l}\text { MnO } \\
\text { wt \% }\end{array}$ & REMARKS \\
\hline $\mathrm{D} 2$ & Massive black with white veinlets and cream lenses & 6.07 & Low manganese oxide content \\
\hline D3 & Massive black with gray white patches & 19.91 & Average $\mathrm{MnO}$ content \\
\hline D11 & Massive black with brown patches and white lenses & 36.54 & High $\mathrm{MnO}$ content \\
\hline D12 & Massive black with brown patches & 58.92 & Higher $\mathrm{MnO}$ content \\
\hline D4 & Massive black with white bands and orange lenses & 19.94 & Average $\mathrm{MnO}$ content \\
\hline D8 & Vuggy: 50-60\% cavities with botryoidal, & 45.41 & High $\mathrm{MnO}$ content \\
\hline D9 & Vuggy: 60-70\%cavities with botryoidal, & 23.23 & Average $\mathrm{MnO}$ content \\
\hline D10 & Vuggy black with $40-50 \%$ cavities & 60.84 & Highest $\mathrm{MnO}$ content \\
\hline D7 & Vuggy with 50-60 \% cavities & 0.93 & Low MnO content \\
\hline D6 & Vuggy: $50-60 \%$ cavities with striations & 0.85 & Low $\mathrm{MnO}$ content \\
\hline D1 & Striations of foliation & 6.07 & Low $\mathrm{MnO}$ content \\
\hline D5 & Fibrous-banded & 1.84 & Low $\mathrm{MnO}$ content \\
\hline
\end{tabular}

The weathered residual oxides and the partially oxidised rock at Yakau and Bofun near Dixcove area were considered. The partially oxidised primary rock is a foliated amphibolite garnet - gneiss and contains garnet $30 \%$, amphiboles $35 \%$, quartz $15 \%$ and ore minerals $5 \%$ with garnet partially replaced by recrystallised quartz and manganese minerals of pyrolusite (see Fig. 4). The manganese oxide rock contains todorokite, pyrolusite and goethite. Garnet is replaced by goethite (see Fig. 5) which contains quartz $20 \%$. The partially oxidised amphibole garnet - gneiss contain manganese oxide of $6.0 \mathrm{wt} \%$, iron oxide of 2.88 wt $\%$ and the highest silica content of 59.44 wt \% (see Fig. 17 and Fig. 18; Table 6).

The petrographic studies of the oxides show they are highly weathered forming massive, vuggy, and fibrous - banded textures with the partially oxidised rock showing striated of foliation (Fig. 6). The residual concentration processes such as oxidation, dissolution and precipitation with the exception of striated foliations [3] may have formed these textures.

The massive type has varieties of black with brown coloration, black with cream veinlets and lenses, massive with cream bands and orange lenses, black with brown patches, black with orange-brown patches with manganese oxide content ranging from 19.9 wt $\%$ to 58.92 wt \% (see Figs. 7 to Fig. 10; Table 3). A plot of MnO against texture also shows that the manganese oxide in the massive type has the highest value of $58.92 \mathrm{wt} \%$ (Fig. 17). The differences in the massive type are associated with the extent of patches, veinlets and lenses (see Figs. 7 to Fig. 10). 


\section{International Journal of Advances in Scientific Research and Engineering (ijasre), Vol 6 (3), March -2020}

The vuggy type has varieties of vuggy brown: 50 - $60 \%$ cavities, vuggy; $40-50 \%$ cavities, vuggy brown; 50 - $60 \%$ cavities with striations, vuggy; $50-60 \%$ cavities with botryoidal, and vuggy brown: $60-70 \%$ cavities with botryoidal (see Figs. 12 to Fig. 16; Table 5), with $\mathrm{MnO}$ ranging from $1.93 \mathrm{wt} \%$ to $60.84 \mathrm{wt} \%$ and iron oxide content of 3.3 to 71.26 wt $\%$. The formation of the vuggy textured oxides could be as result of the dissolution of minerals leaving behind cavities that may have been filled with earthy Fe-rich materials or Mn-rich minerals. From the plot of $\mathrm{FeO}_{\mathrm{t}}$ against sample ID showing variation of $\mathrm{FeO}_{\mathrm{t}}$ with texture, the vuggy brown: $50-60 \%$ cavities with striations (D6) has the highest iron oxide content of 71.44 wt \% and manganese oxide content of 1.86 wt \% (see Fig. 17 and Fig. 18).

The fibrous-banded type is purely brown with fine grains that contain less amount of manganese oxide with a higher iron oxide content. It contains $\mathrm{FeO}_{\mathrm{t}}$ of $61.95 \mathrm{wt} \%$ and $\mathrm{MnO}$ content of $1.84 \mathrm{wt} \%$ (see Table 3). The patches, lenses and veinlets associated with the massive and vuggy textured oxides could be as result of the precipitation and crystallisation of colloidal and non-colloidal solutions that fills cavities and fissures during the residual concentration processes [3].

\subsection{Chemical Characterisation of Ores and Rocks}

[24], examined the dominate materials in a supergene manganese oxide deposit for their role in concentrating the various elements and stated in their research that three main groups are visually identified on the basis of their major constituent; these groups are the Mn oxide ores, ferruginous rocks with an iron oxyhydroxide dominance, and clay- rich material. Here, the dominate minerals in the deposit after comprehensive examination with respect to their corresponding elements are Mn oxides ores, clay - rich material and ferruginous rocks. Multiple regression trends are observed by means of secondary products occurring within the samples. Due to the complex nature of the samples, correlation coefficient is used to analyse the distribution of elements in the rock types. Scatter plots from some selected sample elements are used to investigate relative comparison. Below is a discussion of the relationship of elements between and within, ores and rocks. For example, mineralisation of silicon and aluminium in the rocks occur at a similar ratio showing a positive correlation. The clay-rich group (alumina-silica) shows a well develop regression pattern. These good correlations are generally associated with gangue containing kaolinite [24].

Some elements demonstrate a weaker correlation behaviour with others but same elements show better relation in turn with another. Silicon answers the question here. The plot data for $\mathrm{Al}$ and $\mathrm{Si}$ in fig. 19 gives a correlation coefficient $(\mathrm{r}=1)$ which indicate a better relationship between the two elements. Moreover, the correlation of Si to other elements is poor (e.g., Mn: $r=-$ 0.17655, Fe: $r=-0.57315$, Ti: $r=-0.45214)$. From fig. $22 \mathrm{Ca}$ and $\mathrm{Si}$ have an intermediate correlation coefficient $(\mathrm{r}=0.82947)$ which gives relatively close relationships between the two elements. But, the correlation of Ca to other elements (e.g., K: $\mathrm{r}=-$ 0.29064, Mn: $r=-0.20958$ ) is very poor. From Table 7, elements associated with Mn also establishes a negative correlation within the group

Table 7. Correlation Coefficients for Major Elements

\begin{tabular}{|l|l|l|l|l|l|l|}
\hline $\mathbf{w t} \%$ & $\mathbf{M n O}$ & $\mathbf{F e O}_{\mathbf{t}}$ & $\mathrm{Al}_{\mathbf{2}} \mathbf{O}_{\mathbf{3}}$ & $\mathbf{S i O}_{\mathbf{2}}$ & $\mathbf{T i O}_{\mathbf{2}}$ & $\mathbf{K}_{\mathbf{2}} \mathbf{O}$ \\
\hline $\mathrm{MnO}$ & & -0.70488 & & & -0.45214 & \\
\hline $\mathrm{SiO}_{2}$ & -0.17655 & -0.57315 & 1 & & -0.22072 & \\
\hline $\mathrm{TiO}_{\mathbf{2}}$ & & & -0.22066 & & & \\
\hline $\mathbf{C a O}$ & -0.20958 & & & 0.82947 & & -0.2906 \\
\hline
\end{tabular}




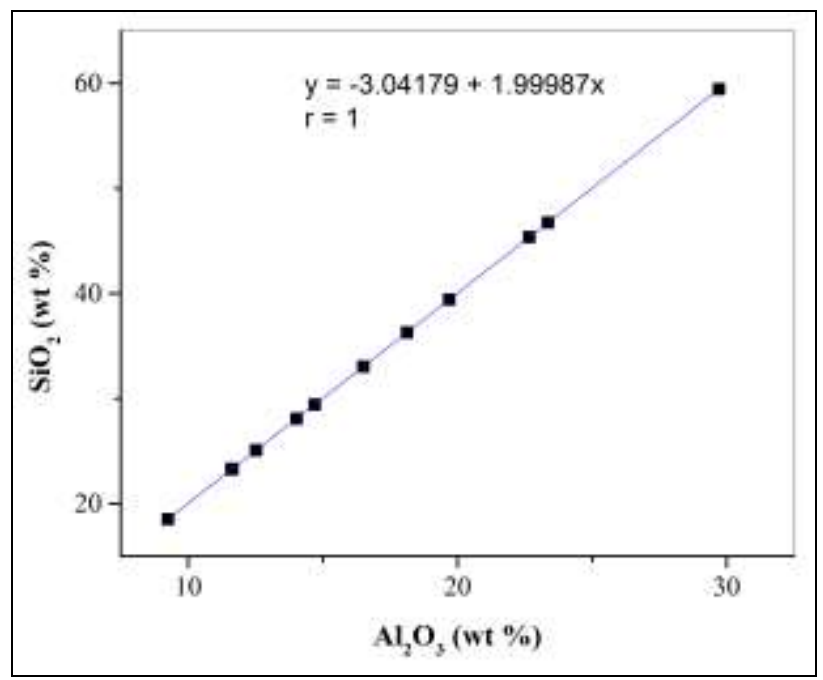

Fig. 19: Correlation of $\mathrm{Si}$ and $\mathrm{Al}$ in ores and rocks.

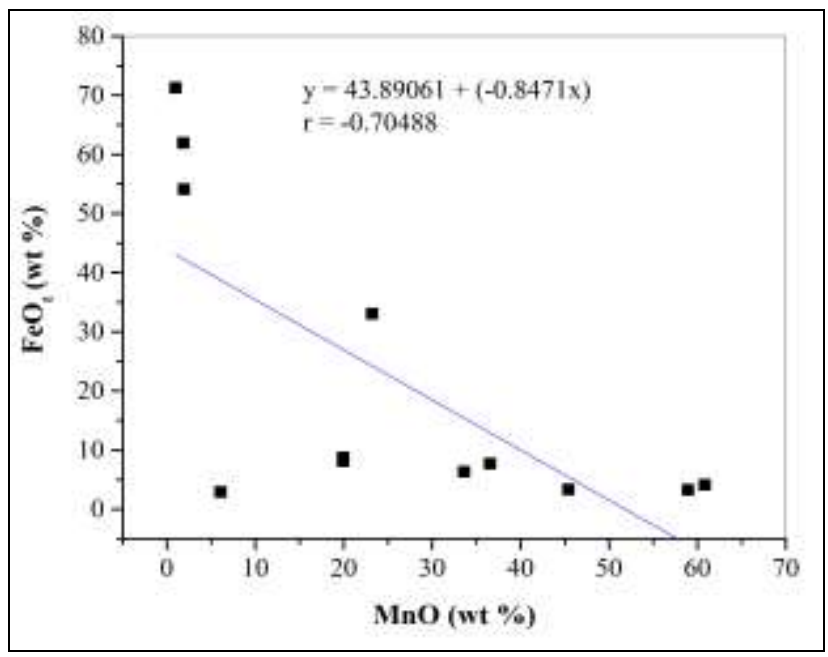

Fig. 20: Correlation of $\mathrm{Fe}$ and $\mathrm{Mn}$ in ores and rocks

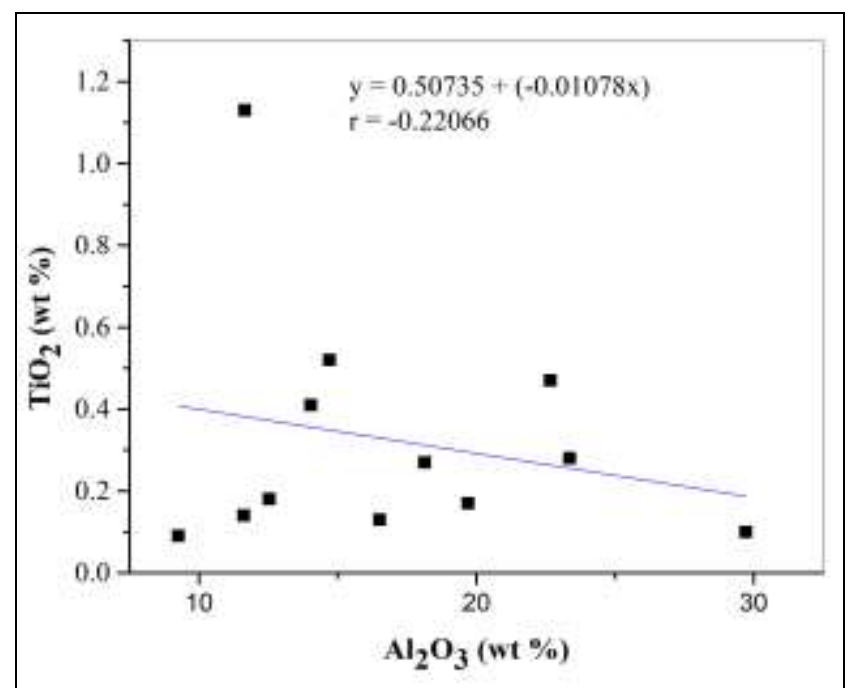

Fig. 21: Correlation of $\mathrm{Ti}$ and $\mathrm{Al}$ in ores and rocks

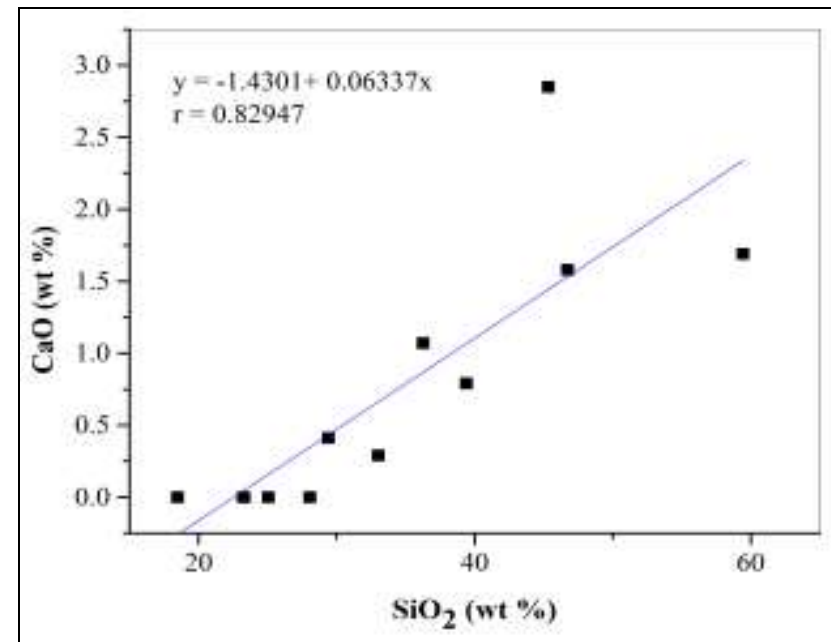

Figure 22: Correlation of $\mathrm{Ca}$ and $\mathrm{Si}$ in ores and rocks

\section{CONCLUSION}

\subsection{Conclusion}

The primary rock of the oxide deposit at Yakau is the partially oxidised rock identified as amphibolite-garnet-gneiss. Concentrations of major oxide of economic interest in the area ranged from $\mathrm{MnO}(0.86-6.85 \mathrm{wt} \%)$ and $\mathrm{FeO}_{\mathrm{t}}(2.88-7.26 \mathrm{wt}$ $\%)$.

The oxide textures of the deposit are, striated foliations, fibrous, massive black with (white veinlets and cream lenses, gray white patches, brown patches and white lenses, brown patches, white bands and orange lenses), vuggy brown: 50-60\% cavities, vuggy: $40-50 \%$ cavities, vuggy brown: $50-60 \%$ cavities with striations, vuggy: $50-60 \%$ cavities with botryoidal, and vuggy brown: $60-70 \%$ cavities with botryoidal textures.

The higher the percentage of cavities and the extent of brown or black coloration of the vuggy textured oxides, the higher the iron oxide or manganese oxide content respectively, hence vuggy: $40-50 \%$ cavities (D10) has the highest MnO content and vuggy brown: $50-60 \%$ cavities with striated type (D6) having the highest iron oxide content.

The massive black textured oxides are manganese oxide rich. The content of manganese oxide is affected by the extent of patches, lenses and veinlets associated with the massive textures, hence the fibrous-banded, vuggy brown: $50-60 \%$ cavities and the vuggy brown: $50-60 \%$ cavities with striations are iron rich oxides with the highest content of iron oxide in the vuggy brown: 50 $-60 \%$ cavities with striations type.

Some elements show strong/positive correlation whereas others show negative/weak correlation. 
International Journal of Advances in Scientific Research and Engineering (ijasre), Vol 6 (3), March -2020

\subsection{Recommendations}

It is recommended that:

$>$ The various stages of oxidation should be studied to know the extent of maturity of the oxides which may contain higher $\mathrm{MnO}$ grades.

$>$ Textures of the residual oxides should be used as an additional tool for mineral exploration.

\section{REFERENCE}

[1] Roy, S. (1976), “Classification of manganese deposits”, Geological Society, London. pp. 67-88.

[2] Roy, S. (1968), "Mineralogy of the different genetic types of manganese deposits", Economic Geology, Vol. 63, pp. 760-786.

[3] Kim, S. L. (1984), "Syngenetic and Epigenetic Textures of Manganese Oxide Ores in the Supergene Weathering Zone", Textures of Ore Minerals and their Genetic Significance, pp.12-15.

[4] Hewett, D. F. and Fleischer, M. (1960), "Deposits of the Manganese Oxides", Economic Geology and the Bulletin of the Society of Economic Geology, Vol. 5, No. 1 pp.1-55.

[5] Beukes, N. J., Swindell, E. P. W., and Wabo, H. (2016), Manganese Deposits of Africa, Department of Geology, University of Johannesburg, South Africa. Vol. 39, No. 2, pp. 299-314.

[6] Kuleshov, V. and Maynard, J. B. (2017), Isotope Geochemistry: The Origin and Formation of Manganese Rocks and Ore, Amsterdam, Elsevier, pp.35-63.

[7] Attoh, K., Evans, M. J., and Bickford, M. E. (2006), "Geochemistry of an UltramaficRodingite Rock Association in the Paleoproterozoic Dixcove Greenstone Belt, SouthWestern Ghana”, Journal of African Earth Sciences, pp. 333-339. 0

[8] Kesse, G. O. (1976), Manganese Ore Deposits of Ghana, Ghana Geological Survey Bulletin, No. 44, 97 pp.

[9] Anon., (2017), "Dixcove" www.wikipedia.com. Accessed: March 5, 2019.

[10] Biveridge Fritz (2014), "A Historical Archaeology Perspective of Cross-culture Encounters at Dixcove and its Neighbourhood, Ghana”, Unpublished PhD Theses, University of Ghana. pp. 108-110.

[11] Anon., (2009), “Cape Three Points", www.tripmondo.com. Accessed: April 6, 2019.

[12] Mucke, A., Dzigbodi-Adjimah K., and Annor, A. (1999), "Mineralogy, petrography, geochemistry and genesis of the Paleoproterozoic Birimian manganese-formation of Nsuta/Ghana”, Mineralium Deposita, Vol. 34, pp. $297-311$.

[13] Leube, A., Hirdes, W., Mauer, R. and Kesse, G.O. (1990), "The early Proterozoic Birimian

Supergroup of Ghana and some aspects of its associated gold mineralisation”, Precambrian Research, Vol. 46, pp.139-165.

[14] Taylor, P. N., Moorbath, S., Leube, A., and Hirdes, W. (1992), "Early Proterozoic Crustal Evolution in the Birimian Ghana: Constraints from Geochronology and Isotope Geology”, Precambrian Research. Vol. 56, pp. 97-111.

[15] Bartholomew, R.W. (1991), The Geology of 1/4 Field Sheets 3 And 5: Axim NE Geological Survey Archival Report, Ghana Mineral Commission, Accra. Vol. 1 and Vol. 2, 7, No. 18, maps and 7 figures, 78 pp.

[16] Loh, G.W., Hirdes A., and Williams, C. (1995), "Geological Map of Ghana; Axim and Sekondi Sheets”, Geological Survey, Ghana, No. 49, pp.149

[17] Oppong, F., Ahenkorah, I., Asebiah, C. D., Osei, B. D. (2018). "Geotechnical Investigation of Fracture Patterns in a Rock Mass during Excavation by Blasting”. International Journal of Advanced Engineering Research and Science. Vol-5, Issue-8. pp. 301

[18] Ahenkorah, I., Awuah, E.M., Ewusi, A., Affam, M., (2018). "Geotechnical and Petrographic Characterisation of the Birimian Granitoids in Southern Ghana as an Aggregates for Sustainable Road Construction". International Journal of Advanced Engineering Research and Science 5. Vol-5, Issue-3. pp 42-41

[19] Post, J. E. (1999), "Manganese oxide minerals: crystal structures and environmental significance", National Academy of Sciences, Washington DC, Vol. 96, pp.34473454.

[20] Crerar, D. A., Cormick, R. K., and Barnes, H. L. (1980), Geology and Geochemistry of Manganese, Varentsov, I. M. and Grasselly, Stuttgart, Vol. 1, pp. 293-334.

[21] Roy, S. (1997), "Genetic diversity of manganese deposition in the terrestrial geological record", Geological Society, London, Vol. 119, pp.5-27.

[22] Dickson, K. B. and Benneh, K. (1973), A New Geography of Ghana, Longman, London, 23pp.

[23] Wills, B. J. (1962), Agriculture and land use in Ghana, Oxford University press, London. pp. 56-60

[24] Pracejus B. and Bolton B. R., (1992). Geochemistry of Supergene Manganese Oxide Deposits, Groote Eylandt, Australia. Economic Geology Vol. 87, pp 1313 